\title{
EASY WORK WITH COMPUTERS IN ENGLISH
}

\author{
L'udovít POLČIC
}

\section{SNADNÉ ZVLÁDNUTÍ POČÍTAČOVÉ ANGLIČTINY}

(Keith Boeckner, P.Charles Brown: Oxford English for Computing, Oxford University Press, 1993, 212 p. ISBN 0-19-457387-7.)

Computer literacy is essential in almost all professions nowadays. The ability of using English computing terminology is undoubtedly important for the work with computers. This book is appropriate for people studying Computer Science or working with computers. It is also suitable for use in universities, technical schools and in company training programs. This book can be used for self-study in conjunction with an Answer book and CD.

This book includes authentic texts and useful listening activities which cover important applications of the virtual reality to the underlying computer processes and components. It contains a glossary of computing terminology and letter writing section. This book is divided into 15 chapters. Each of them has computing part and language part which aims to develop computing vocabulary.

In the first chapter

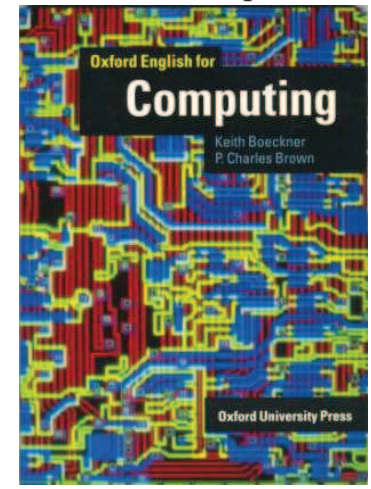
there are explained basic terms and devices in computing; there is explained a function of the processor. The second chapter shows differences among portable computers and discuses the main features of operating systems. In the third chapter on-line services' function is explained. Also there is a section about data transmission. The fourth chapter names the most important programming languages and their features. In the fifth chapter there are compared software packages and also given some facts about computer software. The sixth chapter is devoted to network configurations and explanation of computer networks. Nowadays the biggest problem for computing, the computer viruses are discussed in the seventh chapter. There is even an explanation how they work together with useful terminology and a part about computer security. In the eighth and ninth chapter there a reader can find an easy description what Information systems are. The tenth and eleventh chapter refer to computer usage in medicine and science. They describe the applications of computers which are related to medicine and robotic systems. There is even an easy explanation how robots are constructed. Also the chapter 12 is devoted to futuristic visions. It refers to virtual reality. The chapter 13 describes machine translations. The explanation of the basic terms in multimedia is given in the chapter 14 and the last chapter gives basic terminology in computer graphic.

The book has a modern cover design and smooth surface. The text is logically arranged, each chapter is clearly divided into sections. In conclusion, we can say that this book is easy to read and study from. Of course, it does not substitute other books for particular computer programs but it is a useful book for people who want to gain an important computing vocabulary. Despite of the fact, that this book was firstly published in 1993, it appeared firstly in Slovakia around 2000 .

PaedDr. L’udovít Polčic, PhD.

Katedra techniky a technológií

Fakulta prírodných vied

Univerzita Mateja Bela

Tajovského 40

97401, Banská Bystrica, SR

Tel: + 421484467217

E-mail: polcic@fpv.umb.sk 